\title{
Heterophile Antibodies in Human Transplantation
}

\author{
F. T. RAPAPORT, K. KaNo, and F. Mitgrom \\ From the Department of Surgery and Institute of Reconstructive Plastic \\ Surgery, New York University Medical Center, New York, and the \\ Department of Bacteriology and Immunology, State University of New \\ York at Buffalo, School of Medicine, Buffalo, New York
}

\begin{abstract}
A в S T RACT Sensitization of human recipients with transplantation antigens (leucocytes, skin, or kidney allografts) has resulted in the appearance of serum hemagglutinins directed against sheep, guinea pig, and rat erythrocytes. Such hemagglutinins have been identified as IgG and IgM antibodies. Their appearance was not related to AB0 erythrocyte group incompatibility between donors and recipients, and the antibodies were not of the Forssman or Paul-Bunnel type. The antibody responses appeared to be primarily directed against antigen $(\mathrm{s})$ present on rat erythrocytes, but shared to varying extents by other species. The peak antibody titers occurred in association with allograft rejection. In this regard, they may be of interest as a possible early warning system for the diagnosis and prompt management of rejection crises in clinical organ transplantation.
\end{abstract}

\section{INTRODUCTION}

In 1911, Forssman (1) produced high titers of sheep hemolysins by immunization of rabbits with aqueous suspension of guinea pig organs, which marked the beginning of an intensive period of investigation of the occurrence and distribution in nature of heterophile antigens, i.e., antigens shared by unrelated species. Forssman antigens have been found in the tissues of many mammals, birds, and fish as well as in a wide spectrum of micro-

A partial report of this work was read at the 1st International Congress of The Transplantation Society on 26 June 1967.

Dr. F. T. Rapaport is a Career Scientist of the Health Research Council of the City of New York, Contract 1-349.

Received for publication 29 August 1967 and in revised form 17 October 1967. organisms. Of particular interest to this study is the presence of the Forssman antigen in sheep and its absence in the rat; man is a Forssmannegative species, although Forssman-like antigens have been described in subjects of blood groups $A$ and $A B(2)$.

A multiplicity of other heterophile antigens has been identified since 1911, including antigens shared by human erythrocytes and Gram-negative microorganisms $(3,4)$ and antigens common to group A human erythrocytes and pneumococci (5-7) - pneumococcus Type XIV in particular $(8,9)$. The existence of similar antigens in microorganisms and mammalian tissues has been proposed by many authors as an explanation for the occurrence of serum antibodies encountered in some infectious diseases. Notable examples in this regard are the sheep hemolysins and hemagglutinins described in serum sickness $(10,11)$ and in infectious mononucleosis (12-15), as well as the observation that normal mammalian tissues, such as bovine heart, contain a thermostable, ethanolsoluble substance active as an antigen in the serological tests for syphilis (16).

Kaplan and associates (17-20), Markowitz and associates (21-23), and Zabriskie and Freimer (24) have recently provided cogent evidence of cross-reactions between group A streptococcal antigens and mammalian tissue components, and Brent, Medawar, and Ruszkiewicz (25) have described cross-reactions between pneumococcal polysaccharides and the transplantation antigens of A-strain mice. In addition, the demonstration that heat-killed group A streptococci induce in mice, rats, guinea pigs, and rabbits a state of hypersensitivity to skin allografts, which is indistinguishable from that resulting from pretreatment 
of the recipients with allogeneic tissues (26-30), has provided evidence that stimulation by heterologous antigens may be operative in conditioning host responses to tissue transplants.

In view of the difficulty in demonstrating serum antibodies to tissue allotransplants-particularly before completion of graft rejection and/or excision of the transplant $(31,32)$, it appeared of interest to attempt to extend the concept of an involvement of heterophile antigens in transplantation to an assessment of possible serological components of allograft responses in man. Preliminary observations have indicated that rejection of skin allografts was associated in human recipients with the development of agglutinins against sheep, guinea pig, and rat erythrocytes $(33,34)$. The present report confirms and extends these observations, and analyzes posttransplantation heterophile antibody responses in 49 recipients of leukocyte extracts and skin allografts, and in 22 recipients of kidney transplants. The results are compared with similar antibody determinations performed on sera obtained from 86 normal subjects, 19 multiparous women, and a battery of 30 typing sera recognizing the major leukocyte group antigens of the Hu-1 system of human histocompatibility $(35,36)$.

\section{METHODS}

\section{Human sera}

Skin transplantation sera were obtained from 49 healthy volunteers who served for studies described in detail in previous papers $(37,38)$. Each recipient was sensitized with leukocytes or their fractions and, 2 wk later, received a skin graft from the same donor. The methods for preparation of antigenic materials used for sensitization as well as the procedure of grafting and of graft observation have been described previously (38). Pretreatment serum samples were obtained from each recipient; after sensitization, we collected sequential serum samples at weekly intervals until the 4 th wk after graft rejection.

Sera from 22 kidney allograft recipients were kindly supplied by Drs. S. Anthone and R. Anthone of the Buffalo General Hospital, Buffalo, N. Y., Drs. J. P. Merrill and R. J. Glassock of the Peter Bent Brigham Hospital, Boston, Mass., Drs. D. Hume and G. M. Williams of the Medical College of Virginia, Richmond, Va., and Dr. T. E. Starzl of the Denver Veterans Administration Hospital, Denver, Colo. Pretransplantation sera, as well as a minimum of 10 -serial samples obtained after operation were tested for each patient. The subjects were ABO-group compatible with the graft donors. They were all maintained on standard imunosuppressive therapy with azathioprine and prednisone. The majority of the recipients suffered at least one rejection crisis during the period of testing.

30 leukocyte typing sera recognizing 13 major histocompatibility antigens of the $\mathrm{Hu}-1$ system (35) were obtained through the courtesy of Dr. J. Dausset of the Hôpital Saint-Louis, Paris, France; anti-6A serum was kindly supplied by Dr. J. van Rood, of the University of Leiden. In addition to such typing sera, 19 sera of multiparous women, which contained leukoagglutinins, were included in this study. Sera of 86 healthy blood donors were tested for control purposes. All sera were preserved at $-22^{\circ} \mathrm{C}$ and were inactivated at $56^{\circ} \mathrm{C}$ for $30 \mathrm{~min}$ before use.

\section{Rabbit antisera}

Antisera to the heterophile agglutinins detected in this study were prepared in four albino rabbits. Washed and packed erythrocytes of Wistar-strain rats were mixed with equal volumes of undiluted pooled serum obtained from skin graft recipients BER, BRO, GER, and WEIS, who had formed potent anti-rat hemagglutinins. The mixture was incubated for $1 \mathrm{hr}$ at room temperature. The agglutinated erythrocytes were then washed four times and resuspended to a $10 \%$ concentration in phosphatebuffered saline (PBS), $\mathrm{pH}$ 7.2. Each rabbit received nine intravenous injections of $10 \mathrm{ml}$ of such suspensions at 2-3-day intervals. $1 \mathrm{wk}$ after the last injection, the animals were exsanguinated and the antisera were separated.

Rabbit antiserum to pooled normal human serum purchased from Hyland Laboratories, Los Angeles, Calif., was also used in the course of this study.

\section{Erythrocytes}

Erythrocytes were separated from blood collected in anticoagulant citric acid solution, and were preserved at $4^{\circ} \mathrm{C}$ for not longer than 1 wk. Blood of Wistar-strain rats, Hartley guinea pigs, and rhesus monkeys was obtained in the laboratory. Blood of sheep and oxen was obtained from a slaughter house. Human blood originated from two normal subjects of blood group A and B, respectively. Before use, all erythrocytes were washed three times with PBS.

\section{Hemagglutination tests}

Serum samples tested for the presence of heterophile hemagglutinins were serially diluted in $0.1 \mathrm{ml}$ of a $1 \%$ erythrocyte suspension. The tubes were incubated at room temperature for $1 \mathrm{hr}$ and then centrifuged for $1 \mathrm{~min}$ at $200 \mathrm{~g}$. We took readings in duplicate, grossly, and by microscopic observation, after gentle shaking of the test tubes. The hemagglutinin titers are presented in the text and tables as reciprocals of highest serum dilution at which definite agglutination occurred.

\section{Absorption of human sera}

Transplantation sera which contained high titers of heterophile hemagglutinins were selected for absorption 
experiments; $0.5 \mathrm{ml}$ of washed packed erythrocytes of each species tested (human, ox, sheep, monkey, rabbit, guinea pig, and rat) were added to $1 \mathrm{ml}$ of a $1: 8$ dilution of each serum sample. The mixture was shaken on an electric shaker for $30 \mathrm{~min}$, and was left at room temperature for another $30 \mathrm{~min}$. The suspension was then centrifuged at $1470 \mathrm{~g}$ for $10 \mathrm{~min}$. The supernatant serum was absorbed once more in similar fashion.

\section{Treatment with sulfhydryl compound (39)}

Selected human transplantation serum samples were diluted to $1: 4$ and incubated with equal volumes of $0.2 \mathrm{M}$ 2-mercaptoethanol at $37^{\circ} \mathrm{C}$ for $1 \mathrm{hr}$. They were then immediately used in hemagglutination tests.

\section{Immunoelectrophoresis}

We followed the modification described by Scheidegger (40) using $1.5 \%$ agar in barbital buffer of $\mathrm{pH} 8.6$ at an ionic strength of 0.075 .

\section{Preparative ultracentrifugation}

The procedure of Brakke (41), modified by Fudenberg and Kunkel (42) was used. Briefly, $0.5 \mathrm{ml}$ of serum tested, at a dilution corresponding to 32-64 agglutinating $\mathrm{U}$, was layered over a sucrose density gradient (10-40\%). Separation was performed in a swinging bucket rotor
(Spinco ultracentrifuge) at $95,700 \mathrm{~g}$ for $16 \mathrm{hr}$. Successive fractions were obtained by the drop collection procedure and examined in the hemagglutination test after dialysis against saline.

\section{RESULTS}

\section{Heterophile hemagglutinins in human} transplant recipients

Sera of 49 recipients of human transplantation antigens and skin allografts were tested. In pretreatment serum samples, the mode titers of natural heteroagglutinins were 5 for sheep and guinea pig erythrocytes, and 40 for rat erythrocytes. Rises in titer were observed after skin transplantation in 33 recipients. There were 24 individuals with a minimum eightfold increase in antibody titer against at least one erythrocyte species. Table I lists these individuals; it is noted that 18 recipients had rises in sheep hemagglutinins, with some titers as high as $640 ; 20$ subjects had rises in guinea pig hemagglutinins, in some instances as high as 1280, and 21 individuals had

TABLE I

Heterophile Hemagglutinins in Recipients of Transplantation Antigens and Skin Allografts

\begin{tabular}{|c|c|c|c|c|c|c|c|c|}
\hline \multirow[b]{2}{*}{ Recipient } & \multicolumn{2}{|c|}{ ABO groups } & \multicolumn{3}{|c|}{ Base line hemagglutinin titers } & \multicolumn{3}{|c|}{ Peak hemagglutinin titers after grafting } \\
\hline & Recipient & Donor & Sheep & $\begin{array}{l}\text { Guinea } \\
\text { pig }\end{array}$ & Rat & Sheep & $\begin{array}{l}\text { Guinea } \\
\text { pig }\end{array}$ & Rat \\
\hline $\mathrm{CHE}$ & 0 & 0 & 5 & 5 & 20 & 40 & 160 & 640 \\
\hline WEIN & $\mathbf{0}$ & 0 & 10 & 10 & 20 & 10 & 10 & 640 \\
\hline WEIO & 0 & 0 & 40 & 40 & 40 & 40 & 40 & 320 \\
\hline WEIS & 0 & 0 & 5 & 5 & 10 & 640 & 1280 & 2560 \\
\hline LAM & 0 & 0 & 5 & 5 & 20 & 80 & 1280 & 2560 \\
\hline DES & 0 & 0 & 20 & 40 & 40 & 20 & 40 & 320 \\
\hline KOL & 0 & 0 & 5 & 5 & 20 & 320 & 160 & 160. \\
\hline FRA & 0 & 0 & 5 & 20 & 80 & 80 & 160 & 1280 \\
\hline HOP & 0 & 0 & 5 & 40 & 40 & 40 & 80 & 320 \\
\hline MAI & A & 0 & 5 & 40 & 80 & 80 & 320 & 80 \\
\hline GUN & A & 0 & 5 & 5 & 40 & 40 & 80 & 320 \\
\hline BOR & A & 0 & 80 & 5 & 160 & 80 & 320 & 160 \\
\hline MAR & A & 0 & 5 & 5 & 20 & 160 & 160 & 320 \\
\hline BLO & B & 0 & 5 & 5 & 10 & 320 & 1280 & 1280 \\
\hline IBR & $\mathrm{AB}$ & 0 & 5 & 5 & 5 & 640 & 160 & 640 \\
\hline LEF & A & A & 5 & 5 & 80 & 40 . & 40 & 640 \\
\hline BER & A & A & 5 & 5 & 10 & 640 & 1280 & 2560 \\
\hline BERG & A & A & 5 & 5 & 40 & 5 & 160 & 320 \\
\hline $\mathrm{COH}$ & 0 & A & 5 & 5 & 20 & 40 & 80 & 160 \\
\hline BLA & 0 & A & 10 & 160 & 40 & 10 & 160 & 640 \\
\hline COHE & 0 & A & 20 & 5 & 5 & 320 & 320 & 320 \\
\hline GER & 0 & $\mathbf{A}$ & 20 & 5 & 40 & 160 & 640 & 640 \\
\hline BRO & 0 & A & 5 & 5 & 20 & 80 & 640 & 320 \\
\hline PFE & B & A & 5 & 5 & 10 & 40 & 160 & 10 \\
\hline
\end{tabular}


TABLE II

Heterophile Hemagglutinins in Recipients of Kidney Allografts

\begin{tabular}{|c|c|c|c|c|c|c|}
\hline \multirow[b]{2}{*}{ Subject } & \multicolumn{3}{|c|}{ Base line hemagglutinin titers } & \multicolumn{3}{|c|}{ Peak hemagglutinin titers after grafting } \\
\hline & Sheep & Guinea Pig & Rat & Sheep & Guinea Pig & Rat \\
\hline H.B. & 5 & 5 & 40 & 10 & 5 & 80 \\
\hline $\mathrm{BOI}$ & 5 & 5 & 40 & 5 & 5 & 160 \\
\hline J.D. & 10 & 5 & 80 & 10 & 20 & 320 \\
\hline ROY & 5 & 5 & 20 & 10 & 20 & 320 \\
\hline GRA & $*$ & $*$ & $*$ & 160 & 80 & 1280 \\
\hline RAD & 5 & 5 & 5 & 10 & 5 & 10 \\
\hline R.F. & 5 & 5 & 40 & 5 & 5 & 640 \\
\hline W.W. & 5 & 5 & 5 & 5 & 5 & 20 \\
\hline M.M. & 5 & 5 & 20 & 5 & 5 & 80 \\
\hline WAW & 5 & 5 & 10 & 5 & 5 & 20 \\
\hline LEA & 5 & 5 & 5 & 5 & 5 & 160 \\
\hline SIR & 5 & 5 & 10 & 5 & 5 & 80 \\
\hline DRU & 5 & 5 & 20 & 5 & 5 & 20 \\
\hline LUC & 5 & 5 & 80 & 5 & 5 & 80 \\
\hline ROS & 5 & 5 & 5 & 5 & 5 & 80 \\
\hline PAL & 5 & 5 & 5 & 5 & 5 & 160 \\
\hline HEC & 5 & 5 & 5 & 80 & 5 & 640 \\
\hline LAN & 5 & 5 & 5 & 40 & 20 & 1280 \\
\hline THO & 5 & 5 & 5 & 5 & 5 & 320 \\
\hline HAL & 5 & 5 & 5 & 40 & 5 & 320 \\
\hline DRE & 5 & 5 & 160 & 5 & 5 & 320 \\
\hline SOL & 5 & 5 & 10 & 5 & 5 & 10 \\
\hline
\end{tabular}

* Pretransplantation serum sample of this recipient was not available; the high hemagglutinin levels noted after transplantation suggest, however, that the titers may have increased after the graft.

rises in rat hemagglutinins, in some cases up to 2560.

Peak titers usually appeared within 1 week after application of skin allografts and were, in most instances, associated with graft rejection. ${ }^{1}$ Elevated antibody titers persisted for 2-3 wk after graft rejection, and appeared to be proportional to the intensity of the antigenic stimulus applied to each recipient. The responses were not related to $\mathrm{AB} 0$-group incompatibility between donors and recipients, and were not associated with any rises in anti-A or anti-B isoantibody titers in the AB0incompatible recipients.

The hemagglutinin titers of base line and posttransplantation sera in 22 kidney transplant recipients are summarized in Table II. The most clearcut results were obtained with rat erythrocytes; 20 of 22 subjects had some rise in rat hemagglutinin

\footnotetext{
1 Recently completed studies indicate that sensitization of recipients with transplantation antigens is not a prerequisite for the development of a heterophile antibody response. Similar responses have also been observed after the repeated application of large size skin allografts alone.
}

titer. In 10 instances, the titer increased by a factor of 8 or more after transplantation; the highest titer observed was 1280 .

The results observed appeared in some instances to bear a relation to the clinical state of the patients, since peak antibody titers were associated with impending rejection crises.

Heterophile hemagglutinins in normal individuals and in multiparous women

Titers of 20 provided a useful dividing line between naturally occurring and induced agglutinins to sheep and guinea pig erythrocytes. In the case of rat hemagglutinins, this titer was 40 . As noted in Table III, 26 of 28 normal subjects had anti-sheep erythrocyte antibody titers of 20 or less; 24 of 28 subjects had anti-guinea pig erythrocyte antibody titers of 20 or less, and 78 of 86 individuals had antibodies against rat erythrocytes in titers of 40 or less.

Anti-sheep hemagglutinin titers in multiparous women (whose serum contained leukoagglutinins) did not differ significantly from those observed in 
TABLE III

Comparison of Heterophile Hemagglutinins in Normal Subjects, Multiparous Women, and Hu-1 Leukocyte Typing Sera

\begin{tabular}{|c|c|c|c|c|c|c|c|c|c|c|}
\hline \multirow[b]{2}{*}{$\begin{array}{l}\text { Source of } \\
\text { erythrocytes }\end{array}$} & \multirow[b]{2}{*}{ Subjects under study } & \multirow[b]{2}{*}{$\begin{array}{l}\text { No. of individuals - } \\
\text { in each group }\end{array}$} & \multicolumn{8}{|c|}{ Peak serum hemagglutinin titers } \\
\hline & & & 20 & 40 & 80 & 160 & 320 & 640 & 1280 & 2560 \\
\hline \multirow{4}{*}{ Sheep } & & & \multicolumn{8}{|c|}{ No. of subjects } \\
\hline & 1. Normal subjects & 28 & 26 & 1 & 1 & 0 & 0 & 0 & 0 & $\mathbf{0}$ \\
\hline & 2. Multiparous women & 19 & 18 & 0 & 0 & 1 & 0 & 0 & 0 & 0 \\
\hline & 3. Hu-1 typing sera & 30 & 27 & 3 & 0 & 0 & 0 & 0 & 0 & 0 \\
\hline \multirow[t]{3}{*}{ Guinea pig } & 1. Normal subjects & 28 & 24 & 3 & 0 & 1 & 0 & 0 & 0 & 0 \\
\hline & 2. Multiparous women & 19 & 8 & 2 & 5 & 2 & 2 & 0 & 0 & 0 \\
\hline & 3. Hu-1 typing sera & 30 & 29 & 0 & 0 & 0 & 0 & 1 & 0 & 0 \\
\hline \multirow[t]{3}{*}{ Rat } & 1. Normal subjects & 86 & 48 & 30 & 7 & 1 & 0 & 0 & 0 & 0 \\
\hline & 2. Multiparous women & 19 & 8 & 2 & 5 & 2 & 2 & 0 & 0 & 0 \\
\hline & 3. Hu-1 typing sera & 30 & 22 & 0 & 0 & 6 & 1 & 1 & 0 & 0 \\
\hline
\end{tabular}

normal subjects. 11 out of 19 women, however, exhibited anti-guinea pig hemagglutinin titers exceeding 20 , and 9 of the women had anti-rat hemagglutinin titers above 40 .

A battery of 30 sera recognizing the 13 leukocyte groups of the Hu-1 system was also tested for the presence of heterophile hemagglutinins. Positive reactions were observed in sera recognizing leukocyte groups, $5,7,8,10$, and 11 , but not in sera determining other groups.

Specificity and immunoglobulin character of posttransplantation heterophile hemagglutinins

(a) Absorption experiments. Absorption with human blood group A and/or B erythrocytes was performed in a majority of transplantation sera containing high titers of heterophile antibodies. Extensive absorption leading to complete disappearance of anti-A and/or anti-B isoantibodies did not in any way affect the titer of sheep, guinea pig, or rat hemagglutinins.

Table IV illustrates some representative reactions obtained in the course of cross-absorption experiments designed to assess the specificity of posttransplantation heterophile antibodies. Since many posttransplant sera had the capacity to agglutinate ox and rhesus monkey erythrocytes, these two species were included in the experiment. Erythrocytes from each of the five species tested regularly removed from the serum the hemagglutinating activity directed against that same species. A certain degree of cross-reactivity was also noted, however, in that erythrocytes of each species were capable of absorbing some hemagglutinins directed against the other species. Rat and ox erythrocytes were the most effective cells in this regard.

An anti-6A serum, which gave strong leukoagglutinating reactions with leukocytes positive for group $6 \mathrm{~A}$ of van Rood, was also absorbed with rat erythrocytes. In three consecutive experiments, this procedure completely removed the leukoagglutinating activity of this serum.

(b) Effects of 2-mercaptoethanol. Table V illustrates an experiment designed to assess the effect of 2-mercaptoethanol on posttransplant heterophile antibodies. In this particular experiment, hemagglutinating activity was completely abolished by mercaptoethanol in three sera, but was not significantly affected in the two remaining sera. Similar results were obtained in other experiments ; treatment with 2-mercaptoethanol abolished heterophile hemagglutinating activity in 17 sera; but had no effect upon sera obtained from seven other recipients.

(c) Sucrose density gradient ultracentrifugation studies. Table VI illustrates the results of fractionation of posttransplant sera by sucrose density gradient ultracentrifugation, before and after treatment with 2-mercaptoethanol. The hemagglutinating activity of sera obtained from skin allograft recipients BER and WEIS was recovered in the IgG and IgM containing fractions, while only the IgM containing fractions of sera from kidney allograft subjects LAN and HEC showed such activ- 
TABLE IV

Effect of Absorption with Erythrocytes from Various Species on the Titer of Heterophile Hemagglutinins in Three Transplantation Sera

\begin{tabular}{|c|c|c|c|c|c|c|c|}
\hline \multirow[b]{2}{*}{$\begin{array}{l}\text { Subject } \\
\text { tested* }\end{array}$} & & & \multicolumn{5}{|c|}{ Hemagglutination titer with erythrocytes of } \\
\hline & \multicolumn{2}{|c|}{ Serum used } & Sheep & $\begin{array}{l}\text { Guinea } \\
\text { pig }\end{array}$ & Rat & Ox & $\begin{array}{l}\text { Rhesus } \\
\text { monkey }\end{array}$ \\
\hline \multirow{6}{*}{ BER } & Unabsorbed & & 256 & 256 & 1024 & 64 & 256 \\
\hline & Absorbed with & Sheep & 8 & 8 & 128 & 32 & 8 \\
\hline & $\mathrm{RBC}$ of : & Guinea pig & 64 & 8 & 32 & 64 & 256 \\
\hline & & Rat & 8 & 8 & 8 & 8 & 16 \\
\hline & & $\mathrm{Ox}$ & 8 & 8 & 8 & 8 & 8 \\
\hline & & Rhesus monkey & 128 & 128 & 1024 & 32 & 8 \\
\hline \multirow{6}{*}{ WEIS } & Unabsorbed & & 256 & 256 & 512 & 128 & 512 \\
\hline & Absorbed with & Sheep & 8 & 8 & 32 & 16 & 8 \\
\hline & $\mathrm{RBC}$ of : & Guinea pig & 16 & 8 & 32 & 64 & 256 \\
\hline & & Rat & 8 & 8 & 8 & 8 & 32 \\
\hline & & $\mathrm{Ox}$ & .8 & 8 & 8 & 8 & 8 \\
\hline & & Rhesus monkey & 64 & 128 & 512 & 32 & 8 \\
\hline \multirow{6}{*}{ BLO } & Unabsorbed & & 512 & 128 & 512 & 64 & 128 \\
\hline & Absorbed with & Sheep & 8 & 8 & 64 & 8 & 8 \\
\hline & Absorbed with & Guinea pig & 16 & 8 & 32 & 32 & 64 \\
\hline & $\mathrm{RBC}$ of : & Rat & 8 & 8 & 8 & 8 & 16 \\
\hline & & $\mathrm{Ox}$ & 8 & 8 & 8 & 8 & 8 \\
\hline & & Rhesus monkey & 64 & 128 & 512 & 32 & 8 \\
\hline
\end{tabular}

* Serum specimens used for this experiment were not the same which were used in the titrations reported in Tables I and III.

ity. The hemagglutinating activity of the IgM containing fractions was regularly abolished by treatment of the sera with 2 -mercaptoethanol before ultracentrifugation.

(d) Immunoelectrophoretic studies. In order to obtain further information as to the immunoglobulin nature of the posttransplantation hetero- phile hemagglutinins, we immunized rabbits with rat erythrocytes agglutinated by a pool of four human sera containing potent anti-rat hemagglutinins. The resulting rabbit antisera were studied by immunoelectrophoresis against whole human serum, and against Fraction II thereof. As illustrated in Fig. $1 a$, two lines of precipitation were

TABLE V

Effect of 2-Mercaptoethanol Treatment on Heterophile Hemagglutinins in Transplantation Sera

\begin{tabular}{|c|c|c|c|c|c|c|c|c|c|c|}
\hline \multirow{3}{*}{$\begin{array}{c}\text { Serum } \\
\text { dilutions } \\
\text { used }\end{array}$} & \multicolumn{10}{|c|}{ Anti-rat hemagglutinins in sera from subjects* } \\
\hline & \multicolumn{2}{|c|}{ MAR } & \multicolumn{2}{|c|}{ COHE } & \multicolumn{2}{|c|}{ BLA } & \multicolumn{2}{|c|}{ BERG } & \multicolumn{2}{|c|}{ BER } \\
\hline & $\begin{array}{l}\text { Before } \\
2-\mathrm{Me}\end{array}$ & $\begin{array}{l}\text { After } \\
2-\mathrm{Me}\end{array}$ & $\begin{array}{l}\text { Before } \\
2-\mathrm{Me}\end{array}$ & $\begin{array}{l}\text { After } \\
\text { 2-Me }\end{array}$ & $\begin{array}{l}\text { Before } \\
2-\mathrm{Me}\end{array}$ & $\begin{array}{l}\text { After } \\
2-\mathrm{Me}\end{array}$ & $\begin{array}{l}\text { Before } \\
2-\mathrm{Me}\end{array}$ & $\begin{array}{l}\text { After } \\
2-\mathrm{Me}\end{array}$ & $\begin{array}{l}\text { Before } \\
2-\mathrm{Me}\end{array}$ & $\begin{array}{l}\text { After } \\
\text { 2-Me }\end{array}$ \\
\hline 8 & $++t$ & $\mathbf{0}$ & +++ & 0 & +++ & 0 & $++t$ & $++t$ & +++ & +++ \\
\hline 16 & $+t+$ & 0 & $++t$ & $\mathbf{0}$ & $+t+$ & 0 & $+t+$ & $+t+$ & $+t+$ & +++ \\
\hline 32 . & $+t+$ & 0 & $+t+$ & 0 & $+t+$ & 0 & $++t$ & $++t$ & $++t$ & $+t+$ \\
\hline 64 & +++ & 0 & +++ & 0 & $++t$ & 0 & ++ & ++ & $+t+$ & $++t$ \\
\hline 128 & $++t$ & 0 & ++ & 0 & ++ & 0 & ++ & + & +++ & ++ \\
\hline 256 & ++ & 0 & ++ & 0 & + & 0 & + & 0 & +++ & + \\
\hline
\end{tabular}

* Serum specimens used for this experiment were not the same which were used in the titrations reported in Tables I and III. 


\begin{tabular}{|c|c|c|c|c|c|c|c|c|c|c|}
\hline \multirow[b]{3}{*}{$\begin{array}{l}\text { Fraction } \\
\text { studied }\end{array}$} & \multicolumn{8}{|c|}{ Anti-rat hemagglutinins in posttransplant sera obtained from subjects } & \multirow{2}{*}{\multicolumn{2}{|c|}{$\begin{array}{c}\begin{array}{c}\text { Concurrent sheep } \\
\text { cell hemagglutinin } \\
\text { study in infectious } \\
\text { mononucleosis } \\
\text { serum from }\end{array} \\
\text { W.I. }\end{array}$}} \\
\hline & \multicolumn{2}{|c|}{ BER } & \multicolumn{2}{|c|}{ WEIS } & \multicolumn{2}{|c|}{ LAN } & \multicolumn{2}{|c|}{ HEC } & & \\
\hline & Untreated & $\begin{array}{c}2-\mathrm{Me} \\
\text { treated }\end{array}$ & Untreated & $\begin{array}{c}2-\mathrm{Me} \\
\text { treated }\end{array}$ & Untreated & $\begin{array}{c}2-\mathrm{Me} \\
\text { treated }\end{array}$ & Untreated & $\begin{array}{c}\text { 2-Me } \\
\text { treated }\end{array}$ & Untreated & $\begin{array}{l}\text { 2-Me } \\
\text { treated }\end{array}$ \\
\hline $\begin{array}{l}\text { Fraction } I \text {, } \\
\text { top }\end{array}$ & - & - & - & - & - & - & - & - & - & - \\
\hline $\begin{array}{l}\text { Fraction II, } \\
\text { albumin }\end{array}$ & - & - & - & - & - & - & - & - & - & - \\
\hline $\begin{array}{l}\text { Fraction II, } \\
\text { IgG }\end{array}$ & +++ & +++ & +++ & +++ & - & - & - & - & - & - \\
\hline $\begin{array}{l}\text { Fraction IV, } \\
\text { IgM }\end{array}$ & +++ & - & +++ & - & +++ & - & +++ & n.d. & +++ & - \\
\hline
\end{tabular}

observed; their position was consistent with the IgG and IgM nature of the human serum components to which the immunized rabbits had responded. For comparison purposes, the immunoelectrophoretic pattern produced by rabbit antiserum to whole human serum in illustrated in Fig. $1 b$.



FIGURE 1 Immunoelectrophoresis: top wells in both plates, undiluted normal human serum; bottom wells in both plates, fraction II of pooled normal human serum at a concentration of $40 \mathrm{mg} / \mathrm{ml}$; horizontal trough in Plate a, antiserum from a rabbit immunized with rat erythrocytes agglutinated by posttransplantation human serum; and horizontal trough in Plate b, rabbit antiserum to whole human serum.

\section{DISCUSSION}

Sensitization of human recipients with transplantation antigens-regardless of the source of such antigens (leukocytes, skin, and kidney allografts) -has resulted in rising titers of sheep, guinea pig, and rat hemagglutinins in the recipients.

The immunoglobulin nature of such heterophile hemagglutinins has been established by the observation that rabbits immunized with rat erythrocytes agglutinated by posttransplantation human sera formed antibodies directed specifically against IgG and IgM, but not against other human serum proteins. Mercaptoethanol treatment and sucrose density gradient ultracentrifugation studies have also shown that the heterophile activity of posttransplantation sera was associated with both IgG and IgM. In some recipients, however, the activity was associated with $\operatorname{IgM}$ only.

The description by Eddy, Wheeler, and Diamond (43), and by Davidsohn and Lee (44) of heterophile antibody responses after the injection of blood group substances into human recipients raised the possibility that the antibodies detected in this study were a result of this type of antigenic stimulus. However, absorption of positive sera with human $A$ and/or B erythrocytes failed to remove the heterophile hemagglutinins. In addition, such heterophile antibody responses occurred in many $\mathrm{ABO}$-group compatible donor-recipient 
combinations, and failed to occur in a significant number of $\mathrm{AB} 0$-incompatible situations. It therefore appears to be unlikely that $\mathrm{AB} 0$ group antigens played a significant role in this type of allograft response.

The ability of the heterophile antibodies to agglutinate erythrocytes of Forssman-negative species (rat, monkey, and ox), as well as the capacity of such erythrocytes to absorb posttransplant anti-sheep hemagglutinins exclude the possibility that these antibodies are of the Forssman category. In addition, their strong activity against erythrocytes other than sheep and ox argues against an analogy with the Paul-Bunnell type of antibody.

Results of hemagglutination and cross-absorption experiments suggest that the posttransplantation heterophile antibodies detected in this study are mainly directed against antigen(s) carried by rat erythrocytes, but shared to varying degrees by other species, and especially by bovine erythrocytes. Regardless of the precise nature of these antibodies, however, the results are in agreement with the report of Iwasaki, Talmage, and Starzl (45), who have shown by the indirect antiglobulin consumption test, which utilized sheep erythrocyte stromata as antigen, that IgG antibodies distinct from Forssman antibodies may appear after kidney transplantation.

The presence of this type of heterophile antibody in certain leukocyte grouping sera of the $\mathrm{Hu}-1$ system, but not in others, as well as the observation that only a certain proportion of allograft recipients have developed such antibodies, suggest that these antibodies may constitute a response to tissue isoantigens distributed in group fashion in man. The observation that the leukoagglutinating activity of serum anti-6A of van Rood can be completely absorbed by rat erythrocytes would appear to lend further support to this possibility.

The skin allograft recipients have generally shown higher antibody titers than the kidney transplant patients. This difference may be an expression of the different routes of antigen release invoked in these two categories of subjects (46). It may also be a result of the uremic status of the recipients at the time of kidney transplantation (47), and of the use of immunosuppressive agents in this group of individuals (48).

The data with sera obtained from multiparous women confirm Litschel's (49) report that such sera contain low titers of anti-sheep hemagglutinins. In the present study, such titers seldom exceeded 20. There were slightly higher titers of anti-guinea pig and anti-rat hemagglutinins in this group, although they were not comparable with antibody titers observed in allograft recipients. This observation is in agreement with the concept of the privileged intra-uterine status of the "fetal allograft" (50).

Since peak titers of heterophile antibodies were observed in association with allograft rejection, the possibility should be considered that such antibodies may constitute a response to antigens released or exposed as a result of tissue damage. Such antigens, which could resemble antigens normally present in heterologous species, have been implicated in mechanisms associated with the formation of rheumatoid factor (51) and with the triggering of autoimmune diseases (52). Recent reports of the appearance of rat hemagglutinins in the guinea pig, rabbit, and man as a result of thermal injury (53) lend further support to this interpretation.

The ability of human recipients to develop serum antibody responses to erythrocytes of foreign species after transplantation bears further witness to the ubiquitous nature of the antigenic determinants involved in mammalian allograft reactions (29). Regardless of its origins, this type of immunological reactivity may be of direct pertinence to further studies of the precise nature of human transplantation antigens and of their distribution in group fashion in unrelated individuals. Not all allograft recipients whose serological responses have been assessed in the course of this study developed significant heterophile antibody titers at the time of graft rejection. The presence or absence of this response may indeed be an expression of variations in the antigenic differences existing between donor and recipient. Peak titers of heterophile hemagglutinins-antirat agglutinins in particular-have been associated in a number of instances, however, with skin or kidney allograft rejection. A demonstration of rising titers of heterophile antibodies might therefore provide an early warning system for the diagnosis and prompt management of rejection crises in those cases of clinical organ transplantation where the antigenic differences between donor and 
recipient are capable of evoking this type of response.

\section{ACKNOWLEDGMENTS}

This paper was supported by a grant from The John A. Hartford Foundation, supported in part by grants GM 12748-01 and AI 06754 from the National Institutes of Health, Bethesda, Md., and by Contract 8-1166-796 from the Office of Naval Research, the Department of the Navy, Washington, D. C.

\section{REFERENCES}

1. Forssman, J. 1911. Die Herstellung hochwertiger spezifischer Schafhamolysine ohne Verwendung von Schafblut. Ein Beitrag zur Lehre von heterologer Antikorperbildung. Biochem. Z. 37: 78.

2. Buchbinder, L. 1935. Heterophile phenomena in immunology. Arch. Pathol. 19: 841.

3. Iseki, S. 1952. Blood group substances in bacteria. Gunma J. Med. Sci. 1: 1.

4. Springer, G. F., P. Williamson, and W. C. Brandes. 1961. Blood group activity of gram-negative bacteria. J. Exptl. Med. 113: 1077.

5. Bailey, G. H., and M. S. Shorb. 1931. Heterophile antigen in pneumococci. Am. J. Hyg. 13: 831.

6. Bailey, G. H., and M. S. Shorb. 1933. Immunological relationships of pneumococci and other heterophile antigens and biological significance in pneumococcus infections. Am. J. Hyg. 17: 358.

7. Goebel, W. F., T. Shedlosky, G. I. Lavin, and M. H. Adams. 1943. The heterophile antigen of pneumococcus. J. Biol. Chem. 148: 1.

8. Bullowa, J. G. M. 1937. The management of the pneumonias. Oxford University Press, Inc., New York. 316.

9. Finland, M., and E. C. Curnen. 1938. Agglutinins for human erythrocytes in type XIV antipneumococcic horse serums. Science. 87: 417.

10. Taniguchi, T. 1921. Studies of heterophile antigen and antibody. J. Pathol. Bacteriol. 24: 456.

11. Davidsohn, I. 1930. Further studies on heterophile antibodies in serum sickness. J. Immunol. 18: 31.

12. Paul, J. R., and W. W. Bunnell. 1932. Presence of heterophile antibodies in infectious mononucleosis. Am. J. Med. Sci. 183: 90.

13. Davidsohn, I. 1935. Infectious mononucleosis. Am. J. Diseases Children. 49: 1222.

14. Bailey, G. H., and S. Raffel. 1935. Hemolytic antibodies for sheep and ox erythrocytes in infectious mononucleosis. J. Clin. Invest. 14: 228.

15. Wilkinson, P. C., and D. S. Carmichael. 1964. Immunochemical characterization and serologic behavior of antibodies against red cells in infectious mononucleosis. J. Lab. Clin. Med. 64: 529.

16. Wassermann, A., A. Neisser, and C. Bruck. 1906. Eine serodiagnostische Reaktion bei Syphilis. Deut. Med. Wochschr. 32: 745.

17. Kaplan, M. H., and M. Meyeserian. 1962. An immuno- logical cross-reaction between Group A streptococcal cells and human heart tissue. Lancet. 1: 706.

18. Kaplan, M. H. 1963. Immunologic relation of streptococcal and tissue antigens. I. Properties of an antigen in certain strains of Group A streptococci exhibiting an immunologic cross-reaction with human heart tissue. J. Immunol. 90: 595.

19. Kaplan, M. H., and M. L. Suchy. 1964. Immunologic relation of streptococcal and tissue antigens. II. Crossreaction of antisera to mammalian heart tissue with a cell wall constituent of certain strains of Group A streptococci. J. Exptl. Med. 119: 643.

20. Kaplan, M. H., and K. H. Svec. 1964. Immunologic relation of streptococcal and tissue antigens. III. Presence in human sera of streptococcal antibody cross-reactive with heart tissue. Association with streptococcal infection, rheumatic fever and glomerulonephritis. J. Exptl. Med. 119: 651.

21. Markowitz, A. S., S. H. Armstrong, and D. S. Kushner. 1960. Immunological relationships between the rat glomerulus and nephritogenic streptococci. Nature. 187: 1095.

22. Markowitz, A. S., and C. F. Lange, Jr. 1964. Streptococcal related glomerulonephritis. I. Isolation, immunochemistry and comparative chemistry of soluble fractions from Type 12 nephritogenic streptococci and human glomeruli. J. Immunol. 92: 565 .

23. Markowitz, A. S., R. Clasen, B. D. Nidus, and $H$. Ainis. 1967. Streptococcal related glomerulonephritis. II. Glomerulonephritis in rhesus monkeys immunologically induced both actively and passively with a soluble fraction from human glomeruli. J. Immunol. 98: 161.

24. Zabriskie, J. B., and E. H. Freimer. 1966. An immunological relationship between the Group A Streptococcus and mammalian muscle. J. Exptl. Med. 124: 661.

25. Brent, L., P. B. Medawar, and M. Ruszkiewicz. 1961. Serological methods in the study of transplantation antigens. Brit. J. Exptl. Pathol. 42: 464.

26. Rapaport, F. T., and R. M. Chase, Jr. 1964. Homograft sensitivity induction of Group A streptococci. Science. 145: 407.

27. Chase, R. M., Jr., and F. T. Rapaport. 1965. The bacterial induction of homograft sensitivity. I. Effects of sensitization with Group A streptococci. J. Exptl. Med. 122: 721 .

28. Rapaport, F. T., and R. M. Chase, Jr. 1965. The bacterial induction of homograft sensitivity. II. Effects of sensitization with staphylococci and other microorganisms. J. Exptl. Med. 122: 733.

29. Rapaport, F. T., R. M. Chase, Jr., and A. C. Solowey. 1966. Transplantation antigens activity of bacterial cells in different animal species and intracellular localization. Ann. N. Y. Acad. Sci. 129: 102.

30. Rapaport, F. T. 1968. Heterologous cross-reactions in mammalian transplantation. In Cross-Reacting Antigens and Neo-Antigens. J. Trentin, editor. The Williams \& Wilkins Co., Baltimore. 
31. Milgrom, F., K. Kano, and E. Witebsky. 1965. The mixed agglutination test in studies on human transplantation. J. Am. Med. Assoc. 192: 845.

32. Milgrom, F., B. I. Litvak, K. Kano, and E. Witebsky. 1966. Humoral antibodies in renal homograft. J. Am. Med. Assoc. 198: 226.

33. Rapaport, F. T., K. Kano, and F. Milgrom. 1966. Heterophile antibody and allografts. Lancet. 2: 1131.

34. Rapaport, F. T., K. Kano, and F. Milgrom. 1967. Heterophile hemagglutinins in human skin allograft rejection. Federation Proc. 26: 640 (Abstr.)

35. Dausset, J., P. Ivanyi, and D. Ivanyi. 1965. Tissue alloantigens in humans. Identification of a complex system (Hu-1). In Histocompatibility Testing. Munksgaard, Copenhagen. 51.

36. Dausset, J., and F. T. Rapaport. 1966. The role of blood group antigens in human histocompatibility. Ann. N. Y. Acad. Sci. 129: 408.

37. Rapaport, F. T., H. S. Lawrence, J. M. Converse, and J. H. Mulholland. 1964. Homograft antigen studies in man. Ann. N. Y. Acad. Sci. 120: 280.

38. Rapaport, F. T., J. Dausset, J. M. Converse, and H. S. Lawrence. 1965. Biological and ultrastructural studies of leucocyte fractions as transplantation antigens in man. Transplantation. 3: 490.

39. Deutsch, H. F., and J. I. Morton. 1957. Dissociation of human serum macroglobulins. Science. 125: 600.

40. Scheidegger, J. J. 1955. Une micro-méthode de l'immuno-électrophorèse. Intern. Arch. Allergy Appl. Immunol. 7: 103.

41. Brakke, M. K. 1955. Zone electrophoresis of dyes, proteins and viruses in density-gradient columns of sucrose solutions. Arch. Biochem. Biophys. 55: 175.

42. Fudenberg, H. H., and H. G. Kunkel. 1957. Physical properties of the red cell agglutinins in acquired hemolytic anemia. J. Exptl. Med. 106: 689.
43. Eddy, C. A., R. E. Wheeler, and L. K. Diamond. 1946. Heterophile antibody following administration of blood group specific substances. Proc. Soc. Exptl. Biol. Med. 63: 130.

44. Davidsohn, I., and C. L. Lee. 1966. Heterophilic antibodies following injection of blood group substances. Transfusion. 6: 487.

45. Iwasaki, Y., D. Talmage, and T. E. Starzl. 1967. Humoral antibodies in patients after renal homotransplantation. Transplantation. 5 : 191.

46. Lawrence, H. S., and F. T. Rapaport. 1968. Immunological considerations in transplantation. In Proceedings 3rd International Congress of Nephrology, Washington, D. C. G. Schreiner, editor. 3.

47. Dammin, G. J., N. P. Couch, and J. E. Murray. 1957. Prolonged survival of skin homografts in uremic patients. Ann. N. Y. Acad. Sci. 64: 967.

48. Hitchings, G. H., and G. B. Elion. 1963. Chemical suppression of the immune response. Pharmacol. Rev. 15: 365 .

49. Litschel, E. 1961. On human normal agglutinins to sheep and bovine erythrocytes. Pathol. Microbiol. 24: 954.

50. Billingham, R. E. 1964. Transplantation immunity and the maternal-fetal relation. New Engl. J. Med. 270: 667.

51. Milgrom, F., and E. Witebsky. 1960. Studies on the rheumatoid and related serum factors. I. Autoimmunization of rabbits with gamma globulin. J. Am. Med. Assoc. 174: 56

52. Milgrom, F. 1964. The unusual serology of syphilis, infectious mononucleosis and rheumatoid arthritis. Transfusion. 4: 407.

53. Kano, K., F. Milgrom, and F. T. Rapaport. 1967. Immunologic studies in thermal injury. Heterophile antibodies. Proc. Soc. Exptl. Biol. Med. 125: 100. 